\title{
Perencanaan dan Pengendalian Persediaan Barang Dagang Pada CV. Biji Kopi Makmur Indralaya
}

\author{
Oktariansyah \\ Akuntansi, FE Universitas PGRI Palembang, rianbro82@univpgri-palembang.ac.id
}

\begin{abstract}
ABSTRAK
Penelitian ini dilakukan untuk mengetahui perencanaan dan pengendalian persediaan yang dilakukan yang dilakukan oleh perusahaan CV. Biji Kopi Makmur Indralaya, sehingga perencanaan dan pengendalian persediaan tersebut dapat berjalan dengan teratur bagi perusahaan untuk menekan biaya persediaan dan untuk pengantisipasian kelebihan barang dagangan agar tidak mengalami kerugian. Variable dalam penelitian ini adalah perencanaan dan pengendalian persediaan. Sumber data bersumber dari data internal perusahaan yang melalui dokumentasi. Tehnik analisis yang digunakan yaitu analisis kualitatif dan kuantitatif dengan menggunakan rumus EOQ, ROP dan Safety Stock. Hasil dari penelitian menunjukan bahwa CV. Biji Kopi Makmur Indralaya belum melakukan perencanaan dan pengendalian persediaan dengan teratur atau hanya berdasarkan pengamatan saja sehingga berdasarkan hasil perencanaan dan pengendalian yang dilakukan penulis dapat memberikan beberapa contoh penerapan persediaan yang teratur dan baik. Perencanaan dan pengendalian persediaan yang baik dapat diterapkan dengan menggukan model EQO, penetapan titik ROP dan penetapan Safety Stock sehingga efisssiensi biaya persediaan seperti biaya penyimpan dan biaya pesanan dapat dilakukan yang akhirnya diharapkan dapat meninggkatkan laba perusahaan.
\end{abstract}

Kata Kunci : Perencanaan persediaan, pengendalian persediaan.

\section{A. PENDAHULUAN}

Setiap perusahaan didirikan pada umumnya bertujuan untuk mendapatkan laba. Dalam rangka pencapai tujuannya, seluruh aktivitas perusahaan harus dilaksanakan secara efektif dan efisien dengan rencana yang telah ditetapkan. Informasi yang akurat memegang peranan penting dalam menghadapi persaingan yang komperatif. Kondisi ini menunjukan bahwa untuk memelihara dan mempertahankan efisiensi usaha secara optimal harus selalu menjadi sasaran untuk diusahakan. Semakin luas lingkup kegiatan perusahaan akan semakin banyak pula kegiatan yang dilakukan perusahaan.

Suatu perusahaan yang telah mempunyai pelanggan yang besar harus selalu dapat memenuhi setiap permintaan pelanggan atas produk yang dibutuhkan, agar besarnya permintaan pelanggan tersebut dapat dipertahankan. Kondisi seperti ini menuntut perusahaan untuk harus selalu memilki persediaan yang layak guna menunjang kelancaran operasional perusahaan dalam rangka memenuhi kebutuhan pelanggan.

Perencanaan dan pengendalian amat berperan penting dalam keberhasilan perusahaan mencapai tujuannya. Perencanaan harus dilakukan agar dalam melakukan operasional perusahaan terarah sehingga tujuan dapat tercapai, sedangkan pengendalian juga penting untuk dilaksanakan agar di dapat kepastian bahwa operasi perusahaan dilakukan sesuai dengan rencana yang telah ditetapkan.

Perusahaan industri dan perdagangan, berbagai macam kegiatan operasi perusahaan harus direncanakan dan dikendalikan agar 
perusahaan dapat bertahan dalam persaingan.

Perencanaan dan persediaan merupakan proses yang berkesinambung dalam menetapkan kegiatan untuk mencapai tujuan yang ditetapkan. Perencanaan dan persediaan berhubungan dengan penentuan jumlah persediaan, perencanaan waktu, atau penjadualan dan lokasi untuk memenuhi kebutuhan yang direncanakan.

Persediaan merupakan investasi yang penting dalam memerlukan perhatian yang besar, karena tanpa adanya persediaan yang cukup, maka kelangsungan hidup perusahaan tidak dapat berjalan dengan baik dan pada akhirnya akan mengalami kerugian yang besar.

CV. Biji Kopi Makmur Indralaya merupakan salah satu perusahaan yang bergerak dibidang distributor penjualan berbagai macam produk kopi, seperti kopi Bintang dan kopi Nusantara. Sebagai distributor kopi, CV. Biji Kopi Makmur Indralaya mempunyai pelanggan dalam jumlah yang cukup besar sehingga memerlukan suatu perencanaan dan persediaan yang baik agar dapat memenuhi kebutuhan konsumen akan kebutuhan akan kopi, namun kenyataanya, perencanaan dan persediaan Kopi belum berjalan sebagaimana mestinya.

Kelebihan persediaan menyebabkan besarnya biaya penyimpanan dan biaya pemeliharaan. Kekurangan persediaan akan menyebabkan, perusahaan tidak dapat memenuhi kebutuhan pelanggan dan pada akhirnya akan menimbulkan kerugian yang diperoleh CV. Biji Kopi Makmur Indralaya.

\section{B. KAJIAN TEORI}

\section{1) Perencanaan}

Perencanaan merupakan proses awal dimana manajemen memutuskan tujuan dan cara pencapaianya. Perencanaan adalah hal yang sangat esensial karena dan kenyataanya perencanaan memegang peranan lebih bila dibandingkan dengan fungsifungsi manajemen yang lainya, yaitu pengorganisasian, pengarahan dan pengawasan. Dimana fungsi-fungsi manajemen tersebut merupakan pelaksanaan dari hasil perencanaan.

Menurut Heyzer dan Render (2010:54) Perencanaan bermula dari peryataan dasar misi dan penetapan sasaran. Setelah misi dan sasarannya jelas, Perencanaan melakukan analisis internal dari organisasi untuk mengenali banyak atau sedikitnya setiap kegiatan usaha berperan dalam usaha mencapai misi organisasi.

Menurut Handoko (2010:78) perencanaan adalah suatu proses yang tidak berakhir bila rencana tersebut telah di tetapkan, rencana harus dimplementasikan. Dalam proses penyusunan rencana Handoko (2010:104) menjelaskan :

a. Ruang lingkup

Perencanaan perlu memperhatikan prinsip - prinsip kelengkapan (comprehensivenes), kepaduan dan konsistensi.

b. Efektivitas biaya

Efektivitas biaya perencaan adalah menyangkut waktu, usaha dan aliran emosional.

c. Akuntabilitas

Yang meliputi aspek akuntabilitas perencanaan yaitu tanggung jawab atas pelaksanaan perencanaan dan tanggung jawab atas implementasi rencana.

d. Ketepatan waktu

Para perencana harus memebuat berbagai perencanaan. Perubahaan yang terjadi sangat cepat akan dapat menyebabkan rencana tidak 
tepat atau sesuai untuk berbagai perbedaan waktu.

Adapun kelebihan dari perencanaan menurut Handoko (2010:80) meliputi

a. Membantu manajemen untuk menyesuaikan diri dengan perubahan lingkungan.

b. Membantu dalam kristalisasi persesuaian pada masalah utama.

c. Memungkinkan manajer memahami keseluruhan gambaran operasi lebih jelas.

d. Memebantu penempatan tanggung jawab lebih tepat.

e. Memberikan cara pemberian perintah untuk beroperasi.

f. Memudahkan dala melakukan koordinasi diantara berbagai bagian organisasi.

g. Meminimumkan pekerjaan yang tidak pasti.

h. Menghemat waktu, usaha dan dana.

Sedangkan kelemahan perencanaan menurut Handoko (2010:81) yaitu meliputi :

a. Pekerjaan yang tercakup dalam perencanaan mungkin kelebihan pada kontribusi nyata.

b. Perencanaan cenderung menunda kegiatan.

c. Perencanaan mungkin membatasi manajemen untuk berinisiatif dan berinovasi.

d. Kadang - kadang hasil yang paling baik di dapat dari penyelesaian situasi individual dan penanganan setiap masalah pada saat masalah tersebut terjadi.

e. Ada rencana - rencana yang diikuti cara - cara tidak konsisten.

\section{2) Persediaan}

Menurut Heyzer dan Render (2010:82) Persediaan adalah salah satu aset termahal dari banyak perusahaan mewakili sebanyak $50 \%$ dari keseluruhan modal yang diinvestasikan. Adapun manfaat persediaan menurut Heyzer dan Render (2010:110) antara lain :

Ketidakpastian yang suplai akan dihindarkan

Diskon karena membeli dalam jumlah besar

Efisiensi biaya transportasi dan fluktuasi harga dapat dihindari

Stock pengamanan/ buffer stock dapat menghindari kekosongan

Menghilangkan resiko rendahnya kualitas barang

Mempertahankan stabilitas operasional perusahaan

Optimalisasi mesin/alat

pemakaian

Menjamin kelancaran suplay.

Adapula jenis-jenis persedian menurut Heyzer dan Render (2010:83) meliputi

a. Persediaan bahan baku (raw material)

Yaitu persediaan dari barangbarang yang berwujud yang digunakan dalam proses produksi, barang tersebut dapat diperoleh dari sumber-sumber alam atau dibeli dari pemasok atau perusahaan yang menghasilkan bahan baku dari perusahaan pabrik yang menggunakanya.

b. Persediaan bagian produk atau parts yang dibeli (purchuse parts/company stock)

Yaitu persediaan yang dibeli dari parts yang diterima oleh perusahaan lain, tanpa melalui proses produksi sebelumnya.

c. Persediaan barang-barang pembantu atau barang perlrngkapan (supplies stock) 
Yaitu barang-barang atau bahan baku yang diperlukan dalam proses produksi untuk membantu berhasilnya atau yang dipergunakan dalam kerjanya suatu perusahaan, tetapi tidak merupakan atau komponen dari barang jadi.

d. Pembelian Barang Jadi (finishing goods stock)

Yaitu persediaan barang-barang yang selesai diproses atau diolah dalam pabrik dan siap dijual kepada langganan atau perusahaan lain.

Sedangkan

menurut

Subramanyam dan Wild (2010:279) persediaan merupakan barang yang dijual dalam aktivitas operasional normal perusahaan, dengan pengecualian operasi jasa tertentu, persediaan merupakan aset inti dan penting dalam perusahaan. Jadi, dapat dinyatakan bahwa persediaan merupakan salah satu aktiva berbentuk sejumlah barang yang di simpan untuk berbagai tujuan untuk dijual, digunakan dalam proses produksi, untuk dikonsumsi, untuk pembelian jasa atau di simpan untuk tujuan lain.

Disamping perbedaan jenis dan posisi barang di dalam urutan pengerjaan produk persediaan dapat pula dibedakan menurut fungsinya sebagai berikut :

a. Persediaan Pengaman (safety stock)

Adalah persediaan yang dilakukan untuk mengantisipasi unsur ketidakpastian permintaan dan persediaan. Apabila persediaan pengamanan tidak mampu mengantipikasi ketidak pastian tersebut, maka akan terjadi kekurangan persediaan (stockout).

b. Persediaan Antisapasi (antisipation stock)
Adalah persediaan yang dilakukan untuk menghadapi fluktuasi permintaan yang sudah dapat diperkirakan sebelumnya.

c. Persediaan Dalam pengiriman (translit stock)

Adalah persediaan yang masih dalam pengiriman atau translit.

Menurut Sunyoto (2013:175) langkah pertama dalam pengelolahan persediaan adalah mengidentipikasi semua biaya - biaya yang terkait dengan pembelian yaitu biaya pemesanan dan biaya penyimpanan.

\section{3) Biaya}

Menurut Dunia (2012:22) biaya adalah pengeluar-pengeluaran atau nilai pengorbanan untuk memperoleh barang atau jasa yang berguna untuk masa yang akan datang. Macammacam biaya menurut Dunia (2012:25) yaitu meliputi :

a) Biaya pabrikasi

$>$ Biaya langsung : Biaya yang langsung dalam proses produksi suatu barang, bahan baku.

Biaya tidak langsung : biaya yang dikeluarkan untuk proses produksi

b) Biaya non-pabrik

> Biaya pememasaran yaitu biaya yang diperlukan untuk memperoleh pesanan dan menyediakan produk bagi pelanggan

Biaya administrasi yaitu biaya yangdibutuhkan untuk mengelola organisasi dan menyediakan dukungan bagi karyawan.

Menurut Sunyoto (2013:175) biaya penyimpanan persediaan (Inventory Carrying Cost atau Carrying Cost = CC) adalah biaya yang berhubungan dengan penyimpanan persediaan yang mencakup biaya 
pergudangan, biaya modal dan biaya penyusutan. Jumlah biaya penyimpanan bisa naik turun sebandingan dengan jumlah rata - rata yang telah dimiliki.

Biaya pemesanan (Ording Cost) adalah biaya untuk melakukan pemesanan dan menerima barang pesanan. Biaya ini merupakan biaya tetap yang tidak dipengaruhi oleh jumlah persediaan rata-rata (Sunyoto, 2013 : 178).

\section{4) Perencanaan Persediaan dan Pengendalian Persediaan}

Menurut Dunia (2012:14) perencanaan persediaan yaitu mula mula dirumuskan tujuan dan sasaran yang hendak di capai baik jangka pendek maupun jangka panjang dalam menyiapkan persediaan barang dagang.

Namun menurut Bayangkara (2012:197) pengendalian persediaan harus menjamin bahwa pelayan yang telah diberikan secara tepat beberapa elemen yang harus diperhatikan khusus adalah kualitas produk, ketersediaan produk (jika diinginkan), harga yang kompetitif, persediaan untuk stok pengaman dan penyerahan yang tepat waktu.

Sedangkan menurut Mulyadi (2012 :3) perencanaan dan pengendalian adalah yang digunakan untuk merencanakan kegiatan untuk mencapai sasaran tersebut, serta mengimplentasikan dan memantau pelaksanaan rencana yang telah ditetapkan. Dari definisi tersebut, terdapat tiga kesimpulan berikut ini :

1. Perencanaan sasaran masa depan yang hendak dicapai,

2. Perencanaan kegiatan untuk mencapai sasaran,

3. Pengimplentasian dan pemantauan pelaksanaan rencana a) Hubungan Perencanaan Dengan EOQ (Economic Order Quantity)

Menurut Dunia (2012:37) hubungan perencanaan dengan EOQ yaitu untuk merencanakan persediaan barang dagang yang ekonomis, dimana perencanaan persediaan melalui $E O Q$ atau tingkat pemesanan yang ekonomis (tidak banyak / tidak sedikit) dapat dijadikan dasar untuk melakukan pembelian yang pasti sehingga tidak terjadi kekurangan atau kelebihan persediaan yang diakibatkan oleh situasi yang tidak dinginkan. Jadi untuk merencanakan pemesanan dalam metode ini, pembelian barang akan didapat dalam jumlah yang optimal dan dengan biaya yang minimal.

b) Hubungan Pengendalian dengan EOQ (Economic Order Quantity) Menurut Dunia (2012:76) Hubungan Pengendalian dengan EOQ (Economic Order Quantity) yaitu :

1. Untuk mengendalikan jumlah persediaan pengamanan(safety stock)

Safety stock merupakan persediaan ektra yang harus diaddakan untuk pengamanan dalam menghindari kehabisan persediaan yang diakibatkan oleh situasi yang tidak diinginkan. Situasi tersebut dapat berupa terlambatnya kedatangan barang dan kenaikan pelanggan.

2. Untuk mengendalikan titik pemesanan kembali (Reorder Point/ RoP)

Reorder Point (titik pemesanan kembali) adalah titik waktu dimana sebuah pesanan baru harus dilakukan atau persiapan dimulai, hal ini merupakan fungsi $\mathrm{EOQ}$, tenggang waktu (lide time) dan titik dimana persiapan hampir habis. 
3. Untuk mengendalikan masa waktu tenggang (idle time)

Lead time merupakan waktu diantara pelaksanaan pesanaan dan datanya pesanan.

c) Penentuan Jumlah Pemesanan Ekonomis

Menurut Sunyoto (2013:179) salah satu model yang paling sering digunakan adalah model economic order quantity (EOQ). Model ini EOQ adalah suatu rumus untuk menentukan jumlah pemesanan yang akan meminimumkan total biaya persediaan. Adapun pemikiran dalm model ini yaitu

1. Kalau perusahaan memliki persediaan rata - rata yang besar, untuk jumlah kebutuhan yang sama dalam satu periode berarti perusahaan tidak perlu melakukan pembelian terlalu sering. Jadi menghemat biaya pembelian atau biaya pemesanan.

2. Tetapi kalau perusahaan membeli dalam jumlah besar sehingga bisa menghemat biaya pemesanan, perusahaan akan menanggung biaya pemesanan yang besar pula, berarti menanggung biaya penyimpanan yang terlalu tinggi.

3. Karena itu perlu dicari jumlah yang membuat biaya persediaan terkecil. Biaya bersediaan adalah biaya penyimpanan ditambah biaya pemesanan.

d) Penentuan Titik Pemesanan Kembali (Reorder Point)

Menurut Sunyoto (2013:183) jika Pemesanan harus dilakukan sebelum pesanan diterima maka akan timbul persediaan barang dalam perjalanan. Barang dalam perjalanan (good in transit) adalah barang yang sudah dipesan tetapi belum diterima. Persediaan barang alam perjalanan akan timbul jika waktu yang normal untuk menunggu pengiriman lebih panjang dari pada waktu antara pemesanan yang satu dengan pemesanan berikutnya. Adapun cara sederhana dengan mengurangi barang dalam perjalanan pada waktu menghitung titik pemesanan ulang.

\section{e) Penentuan \\ Persediaan \\ Pengamanan (Safety stock)}

Menurut Sunyoto (2013:184)

Persediaan pengaman (safety stock) adalah persediaan tambahan yang dimiliki untuk berjaga - jaga terhadap perubahan tingkat penjualan dan kelambatan produksi atau pengiriman. Persediaan pengamanan yang optimum berubah - ubah dari satu situasi ke situasi yang lainnya, tetapi biasanya ia meningkat jika :

1. Perkiraan Penjualan tidak menentu

2. Biaya (akibat hilangnya kesempatan menjual dan cemarnya citra perusahaan) karena kekurangan persediaan makin besar.

3. Kemungkinan tertundanya penerimaan barang pesanan semakin besar pula.

Sedangkan disisi lain persediaan pengaman yang optimum menurun jika biaya penyimpanan meningkat. Disamping itu juga persediaan pengamanan berguna untuk berjaga - jaga terhadap keterlambatan penerimaan pesanan.

Dari pemikiran diatas bahwa perencananaan persediaan barang dagang dapat dimulai dari penetapan biaya - biaya yaitu biaya pemesanan, biaya penyimpanan dan biaya perawatan dimana semua biaya tersebut sudah dihitung dan dipastikan anggaranya, setelah itu baru dapat melakukan pengendalian persediaan barang dagang dengan menggunakan metode EOQ, ROP, dan Safety Stock. 


\section{METODE PENELITIAN}

Menurut Sugiyono (2013:2)

Diartikan sebagai cara ilmiah untuk mendapatkan data dengan tujuan dan kegunaan tertentu. Metode penelitian yang digunakan dalam penelitian ini yaitu menggunakan metode Komperatif adalah suatu penlitian yang bersipat membandingkan. Disini variablenya mandiri tetapi untuk sampel yang lebih dari satu, atau dalam waktu yang berbeda.

\section{POPULASI DAN SAMPEL}

Menurut Sugiyono (2013:115), populasi adalah wilayah generalisasi yang terdiri dari objek pajak yang mempunyai kualitas dan karakteristik tertentu yan diterapkan oleh penelitian untuk mempelajari dan kemudian ditarik kesimpulan. Yang akan menjadi populasi dalam penelitian ini adalah keseluruhan data penjualan pada CV. Biji Kopi Makmur Indralaya.

Sedangkan sampel menurut Sugiyono (2013:116) adalah bagian dari jumlah dan karekteristik yang dimiliki oleh populasi tersebut. Sampel dalam penelitian ini yaitu data penjualan produk kopi 2016-2017 pada CV. Biji Kopi Makmur Indralaya.

\section{F. TEHNIK PENGUMPULAN DATA} Menurut Sugiyono (2013:193), dalam pengumpulan data yang diperlukan penulis menggunakan penelitian jenis data skunder. Data skunder yaitu melengkapi data-data dan keterangan yang di dapatkan melelui studi pustaka, wawancara dan observasi serta referensi yang di dapatkan melalui studi pustaka, wawancara, dan observasi serta referensi yang ada, baik itu bersumber dari buku pedoman, literatur yang disusun oleh para ahli yang berhubungan dengan masalah.
G. TEHNIK ANALISIS DATA

Ada 2 metode yang digunakan dalam penelitian ini yaitu :

1. Metode analisis kualitatif yaitu tehnik penganalisaan data yang bukan berbentuk skala rasio tetapi dengan cara diperbandingkan sehingga menjawab permasalahan yang dirumuskan.

2. Metode analisis kuantitatif yaitu tehnik penganalisaan data yang diambil berdasarkan sampel sehingga dapat di hitung untuk mendapatkan hasil yang kokoh.

Metode yang digunakan dalam penelitian ini yaitu metode analisis kualitatif dan kuantitatif yang akan menjelaskan pernasalahan tersebut dengan menggunakan angka - angka atau perhitungan memggunkan rumus di bawah ini.

\section{H. HASIL PENELITIAN}

Sejak berdirinya sampai sekarang CV. Biji Kopi Makmur Indralaya telah melakukan berbagai macam aktivitas usahanya antara lain :

\section{Pembelian}

CV. Biji Kopi Makmur Indralaya Melakukan pembelian berbagai jenis kopi dari perusahaan kopi tersebut. Pemesanan pembelian untuk setiap jumlah dilakukan tidak secara rutin untuk jangka waktu tertentu, tetapi tergantung dari banyak kopi yang dibutuhkan oleh konsumen.

Kebutuhan kopi harus tetap tersedia di perusahaan dan biasanya lebih sering diadakan pemesanan guna mengisi persediaan didalam gudang karena banyaknya kopi yang dipesan atau di beli, maka perlu dibuat sautu daftar pembelian, menurut direktur CV. Biji Kopi Makmur Indralaya dengan asumsi sebagai berikut : 
a. Kopi yang setiap saat diandalkan (diutamakan

pembelian/pemesanan) seperti kopi seruit dan kopi binder

b. Kopi seruit dan kopi binder yang dipesan pembelinya dapat dilakukan dengan cepat.

\section{Penjualan}

Dalam melakukan kegiatan usahanya yang berupa penjualan kopi, yang dilakukan oleh CV. Biji Kopi Makmur Indralaya yaitu dengan dua cara penjualan :

a) Penjualan Tunai

Penjualan ini dilakukan berdasarkan pesanan yag masuk pada umumnya berasl dari pedagang lain, Seperti warung, cafe, toko dan intansi-intansi.

b) Penjualan Kredit

Penjualan secara kredit pada umumnya dapat dilakukan dengan mengakan perjanjian yang dilaksanakan setelah mendapat surat pesanan perusahaan organisasi yang membutuhkan kopi tersebut.

\section{Pembukuan}

Bagian pembukuan CV. Biji Kopi Makmur Indralaya melakukan pembukuan untuk semua transaksi yang terjadi baik transaksi pembelian kedalam akun pembelian dan dan membukukan semua penjualan yang keluar melalui pesan yang dibayar tunai ataupun kredit, Karena penjualan yang bersipat rutin dan terus menerus.

Bagian Pembukuan mencatat atau membukukan pengeluaran atau ongkos untuk keperluan CV. Biji Kopi Makmur Indralaya. Seperti pembayaran rekening listrik, air, telepon, alat kantor, ongkos, transportasi, ongkos makan karyawan, dan pengeluaran rutin lainnya.

\section{Pelaksanaan Perencanaan dan Pengendalian Persediaan}

a) Perencanaan persediaan kopi Seruit dan kopi Binder

Perencanaan

persediaan

berhubungan dengan masalah penentuan komposisi persediaan, penentuan waktu dan penjaduwalan serta alokasi untuk memenuhi berapa kebutuhan perusahaan yang diproyeksi perencanaan persediaan yang baik adalah harus menghindarkan pengakumulasian yang berlebihan dan tidak selayaknya, untuk menentukan jumlah pembelian persediaan yang tepat dan sesuai dengan kebutuhan perusahaan.

Perencanaan persediaan yang ditargetkan CV. Biji Kopi Makmur Indralaya adalah dengan melakukan pemesanan kopi seruit 3 kali dan kopi binder sebanyak 4 kali dalam 1 dan lama waktu pemesanan selama 3 hari dan pada tahun 2017 CV. Biji Kopi Makmur Indralaya melakukan pemesan sebanyak 6 kali pada 2016, dalam sekali pesanan sebanyak 11 pack untuk kopi seruit dan 23 pack untuk kopi binder. dalam 1 bulan pada tahun 2016 dan 2017. Dalam 1 pack kopi tersebut berisi 20 bungkus. CV. Biji Kopi Makmur Indralaya hanya melakukan perkiraan saja dimana tidak menentukan jumlah persediaan yang harus ada dalam 1 tahun, juga dalam menentukan persediaan maksimum berdasarkan perakiraan bagian pembelian perusahaan. Perencanaan pemesanaan yang dilakukan $\mathrm{CV}$. Biji Kopi Makmur Indralaya dimulai dari pegawai bagian gudang yang mengecek kuantitas persediaan kopi tersebut, kemudian bagian gudang membuat surat pesanan dan melaporkan kepada direktur CV. Biji Kopi Makmur Indralaya jika telah disetujui maka bagian gudang memberikan surat pesanan tersebut ke bagian pembelian agar dapat 
direalisasikan, sebelum merealisasikan pembelian terlebih dahulu melakukan negosiasi dengan para pemasok hal ini dilakukan agar dapat dibeli kopi tersebut dengan harga yang lebih murah dan diterima serta disimpan bagian gudang.

Data pelaksanaan perencanaan persediaan kopi seruit dan kopi binder yang ada pada CV. Biji Kopi Makmur Indralaya yaitu terdiri dari :

1) Data Pembelian

Tabel 1

Pembelian Kopi Seruit dan Kopi Binder

Tahun 2016-2017

\begin{tabular}{|c|c|c|c|c|c|c|}
\hline \multirow{2}{*}{ Persediaan } & \multicolumn{3}{|c|}{ Tahun 2016 } & \multicolumn{3}{c|}{ Tahun 2017 } \\
\cline { 2 - 7 } & $\begin{array}{c}\text { Kebutuhan } \\
\text { Pertahun }\end{array}$ & $\begin{array}{c}\text { Harga } \\
\text { (Rp) }\end{array}$ & $\begin{array}{c}\text { Total } \\
\text { (Rp) }\end{array}$ & $\begin{array}{c}\text { Kebutuhan } \\
\text { pertahun }\end{array}$ & $\begin{array}{c}\text { Harga } \\
\text { (Rp) }\end{array}$ & $\begin{array}{c}\text { Total } \\
\text { (Rp) }\end{array}$ \\
\hline $\begin{array}{c}\text { Kopi Seruit } \\
\text { (pack) }\end{array}$ & 4.500 & 50.000 & 225000.000 & 6000 & 50.000 & 300.000 .000 \\
\hline $\begin{array}{c}\text { Kopi Binder } \\
\text { (pack) }\end{array}$ & 5.000 & 60.000 & 300.000 .000 & 5000 & 60.000 & 300.000 .000 \\
\hline
\end{tabular}

Sumber : CV. Biji Kopi Makmur Indralaya

Dari data diatas diketahui bahwa pembelian kopi seruit sebanyak 4500 pack dengan harga Rp. 50.000 jadi total harga pembelian kopi seruit sebesar Rp. 225.000.000 pada tahun 2016, lalu pada tahun 2017 pembelian kopi seruit sebanyak 6000 pack dengan harga Rp. 50.000 jadi total pembelian kopi binder sebesar
Rp.300.000.000,. dan juga pembelian kopi binder sebanyak 5000 pack dengan harga Rp.60.000 jadi total harga pembelian kopi binder sebesar Rp. 300.000 .000 pada tahun 2016, Ialu pada tahun 2017 pembelian kopi ADC sebanyak 5000 pack dengan harga Rp. 60.000 jadi total pembelian kopi binder sebesar Rp.300.000.000,.

2) Data Penjualan

Tabel 2

Penjualan Kopi Seruit dan Kopi Binder

Tahun 2016-2017

\begin{tabular}{|c|c|c|c|c|c|c|}
\hline \multirow{2}{*}{ Persediaan } & \multicolumn{3}{|c|}{ Tahun 2016 } & \multicolumn{3}{c|}{ Tahun 2017 } \\
\cline { 2 - 7 } & $\begin{array}{c}\text { Kebutuhan } \\
\text { Pertahun }\end{array}$ & $\begin{array}{c}\text { Harga } \\
\text { (Rp) }\end{array}$ & $\begin{array}{c}\text { Total } \\
\text { (Rp) }\end{array}$ & $\begin{array}{c}\text { Kebutuhan } \\
\text { pertahun }\end{array}$ & $\begin{array}{c}\text { Harga } \\
\text { (Rp) }\end{array}$ & $\begin{array}{c}\text { Total } \\
\text { (Rp) }\end{array}$ \\
\hline $\begin{array}{c}\text { Kopi seruit } \\
\text { (pack) }\end{array}$ & 4.000 & 50.000 & 200.000 .000 & 6000 & 50.000 & 300.000 .000 \\
\hline $\begin{array}{c}\text { Kopi binder } \\
\text { (pack) }\end{array}$ & 5.000 & 60.000 & 300.000 .000 & 4000 & 60.000 & 240.000 .000 \\
\hline
\end{tabular}

Sumber : CV. Biji Kopi Makmur Indralaya

Dari data diatas diketahui bahwa penjualan kopi seruit sebanyak 4000 pack dengan harga Rp. 50.000 jadi total harga penjualan kopi seruit sebesar Rp. 200.000.000 pada tahun 2016, Ialu pada tahun 2017 penjualan 
kopi seruit sebanyak 6000 pack dengan harga Rp. 50.000 jadi total pembelian kopi seruit sebesar Rp.300.000.000,. Dan juga penjualan kopi binder sebanyak 5000 pack dengan harga Rp.60.000 jadi total harga penjualan kopi binder sebesar Rp. 300.000.000 pada tahun 2016, Ialu pada tahun 2017 penjualan kopi bindersebanyak 4000 pack dengan harga Rp. 60.000 jadi total penjualan kopi binder sebesar Rp.240.000.000,.

Tabel 3

Penawaran Kopi Seruit dan Kopi Binder Yang Tidak Terpenuhi Tahun 2016-2017

\begin{tabular}{|c|c|l|c|c|c|c|}
\hline & \multicolumn{3}{|c|}{ Kopi Seruit } & \multicolumn{3}{c|}{ Kopi Binder } \\
\cline { 2 - 7 } $\begin{array}{l}\text { Tahun } \\
\text { (Dalam pack) }\end{array}$ & $\begin{array}{l}\text { Persediaan } \\
\text { yang keluar }\end{array}$ & $\begin{array}{l}\text { Persediaan } \\
\text { yang } \\
\text { terpenuhi }\end{array}$ & $(\mathbf{+})$ & $\begin{array}{l}\text { Persediaan } \\
\text { yang keluar }\end{array}$ & $\begin{array}{l}\text { Persediaan } \\
\text { yang } \\
\text { terpenuhi }\end{array}$ & $(\mathbf{( + )}$ \\
\hline 2016 & 4.000 & 4.500 & 5.00 & 6.000 & 5.000 & 1.000 \\
\hline 2017 & 5.000 & 6.000 & 1.000 & 5000 & 4.000 & 1000 \\
\hline
\end{tabular}

Sumber : CV. Biji Kopi Makmur Indralaya

Dari data penawaran diatas, pada tahun 2016 jumlah penawaran terpenuhi kopi seruit sebesar 4000 pack dan jumlah penawaran yang tidak terpenuhi sebanyak 500 pack, dan kopi binder sebanyak 1000 pack, dan pada tahun 2017 jumlah penawaran kopi seruit yang terpenuhi sebanyak 5000 pack, dan penawaran yang tidak terpenuhi 1000 pack, lalu kopi binder penawaran yang terpenuhi sebanyak 4000 dan yang tidak terpenuhi sebanyak 1000 pack.

\section{b. Pengendalian Persediaan Kopi Seruit dan Kopi Binder \\ Pengendalian persediaan} meliputi pengendalian kualitas dan kuantitas dalam batas-batas yang telah direncanakan dan perlindungan fisik persediaan. Perencanaan persediaan tidak dapat berjalan dengan baik, jika tidak ada pengendalian persediaan dengan baik, karena dalam hal ini semua bagian yang berkaitan harus melakukan kegiatan pemeriksaan, pengecekan dan berbagai tindakan agar dapat dikendalikan. Pengendalian secara fisik yang dilaksanakan CV. Biji Kopi Makmur Indralaya dimulai dari adanyan tempat penyimpanan kopi lebih difokuskan kepada pengamatan tempat persediaan kopi tersebut, agar terhindar dari pencurian serta kerusakan yang mungkin terjadi.

CV. Biji Kopi Makmur Indralaya dalam melaksanakan pengendalian secara kualitas fisik persediaan mempekerjakan 4 orang petugas khusus pada bagian gudang penyimpan kopi tersebut., serta menggunakan tempat penyimpanan kopi yang baik dengan satu pintu keluar dan masuknya.

\section{Pembahasan}

Perencanaan merupakan suatu proses yang berkelanjutan untuk menetapkan kejadian dan kegiatan yang diperlukan untuk mencapai tujuan yang telah ditetapkan, sedangkan pengendallian berasumsi sebagai suatu tindakan pengaturan dan pengarahan pelaksanaan yaitu dengan maksud agar tujuan dapat tercapai. Jika jumlah persediaan lebih besar mak akan memperbesar biaya penyimpanan dan pemeliharaan serta memperbesar kemungkinan kerugian karena kerusakan, sehingga akan 
memperbesar

pengeluaran

perusahaan.

Persediaan merupakan elemen penting dan utama dalam operasi perusahaan, dalam pengelohan terhadap persediaan kopi pada CV. Biji Kopi Makmur Indralaya belum berjalan dengan baik. Perusahaan dalam menentukan jumlah persediaan yang dibutuhkan hanya memakai satu metode saja tanpa melakukan pertimbangan lain, sehingga tidak ada patokan yang dipakai guna menentukan kuantitas pembelian. Waktu pembelian persediaan dapat dilakukan dengan cara melihat jumlah persediaan pengamanan yang ditetapkan oleh perusahaan, apabila jumlah persediaan sudah mencapai batas persediaan pengaman, maka CV. Biji Kopi Makmur Indralaya melakukan pembelian atas kopi tersebut. Dasar perhitungan persediaan pengaman, persediaan minimum maupun maksimum. Hasil dari perhitungan dengan metode $\mathrm{EOQ}$ ini dapat digunakan CV. Biji Kopi Makmur Indralaya sebagai dasar dalam melakukan pembelian kopi. Dengan metode ini, pembelian kopi akan dapat dalam jumlah yang optimal dan dengan biaya yang minimal.

Tabel 4

Pengendalian Persediaan Kopi Seruit dan Kopi Binder Tahun 2016 - 2017

\begin{tabular}{|c|c|c|c|c|c|c|c|}
\hline \multirow{2}{*}{$\begin{array}{c}\text { Persediaan } \\
\text { (dalam bungkus) }\end{array}$} & \multicolumn{2}{|c|}{$\begin{array}{c}\text { Kebutuhan } \\
\text { pertahun }\end{array}$} & \multicolumn{2}{c|}{$\begin{array}{c}\text { Kebutuhan } \\
\text { Rata-rata } \\
\text { perhari }\end{array}$} & \multicolumn{2}{c|}{$\begin{array}{c}\text { Lead time } \\
\text { perhari }\end{array}$} & \multirow{2}{*}{$\%$} \\
\cline { 2 - 8 } & $\mathbf{2 0 1 6}$ & $\mathbf{2 0 1 7}$ & $\mathbf{2 0 1 6}$ & $\mathbf{2 0 1 7}$ & $\mathbf{2 0 1 6}$ & $\mathbf{2 0 1 7}$ & \\
\hline Kopi Seruit & 4.500 & 6.000 & 69 & 77 & 3 & 3 & 10 \\
\hline Kopi Binder & 5.000 & 5.000 & 44 & 47 & 3 & 3 & 10 \\
\hline
\end{tabular}

1. Pesanan yang ekonomis atau EOQ ( Econimoc Order Point )

- EOQ Dalam Unit

$$
\mathrm{EOQ}=\sqrt{\frac{2 \times R U \times C O}{C U \times C C}}
$$

-EOQ Dalam Rupiah

$\mathrm{EOQ}=\sqrt{\frac{2 \times R U \times C U \times C O}{C C}}$

Keterangan :

EQO : Jumlah pesanan yang ekonomis

RU : Kebutuhan barang setiap periode

CU : Biaya Barang per unit

CO : Biaya pesanan per pesanan

CC : Persantase biaya penyimpanan (EOQ)
Sebelum melakukan kuantitas terlebih dahulu dapat diuraikan dari variabel rumus sebagai berikut :

a. Kebutuhan Kopi Seruit dan Kopi Binder setiap Periode (RU)

Sebagaimana yang tersaji dalam tabel 4 bahwa kopi kebutuhan kopi seruit tahun 2016 adalah sebesar 4.500 pack, dan kopi binder sebesar 5.000 pack, dan pada tahun 2017 kebutuhan kopi seruit sebesar 6.000 dan kopi binder sebesar 5.000 packnya.

b. Biaya pesanan perpesanan (CO) Biaya yang terjadi sehubungan dengan frekuensi pemesanan kopi seruit dan kopi binder yang dilakukan oleh CV. Biji Kopi Makmur Indralaya seperti biaya persiapan 
pesanan, biaya penerimaan dan biaya pemasukan kopi seruit dan kopi binder ke gudang dan biaya proses pembayaran adalah sebagai berikut :

Tabel 5

Biaya Pesanan Per Pesanan Tahun 2016

\begin{tabular}{|l|l|c|}
\hline No & Keterangan & Biaya (Rp) \\
\hline 1. & Biaya Persiapan Pesanan & 1.000 .000 \\
\hline 2. & Biaya penerimaan dan pemasukan ke gudang & 1.000 .000 \\
\hline 3. & Biaya proses pembayaran & 1.200 .000 \\
\hline \multicolumn{2}{|c|}{ Jumlah } & $\mathbf{3 . 2 0 0 . 0 0 0}$ \\
\hline
\end{tabular}

Sumber : CV. Biji Kopi Makmur Indralaya

Tabel 6

Biaya Pesanan Per Pesanan Tahun 2017

\begin{tabular}{|l|l|c|}
\hline No & Keterangan & Biaya (Rp) \\
\hline 1. & Biaya Persiapan Pesanan & 1.000 .000 \\
\hline 2. & Biaya penerimaan dan pemasukan ke gudang & 1.000 .000 \\
\hline 3. & Biaya proses pembayaran & 1.400 .000 \\
\hline \multicolumn{2}{|c|}{ Jumlah } & $\mathbf{3 . 4 0 0 . 0 0 0}$ \\
\hline
\end{tabular}

Sumber : CV. Biji Kopi Makmur Indralaya

c. Harga Pembelian Kopi Seruit dan Kopi Binder

Harga pembelian kopi seruit per pack adalah $\mathrm{Rp} 50.000$ dan kopi binder sebesar Rp 60.000 per packnya.

\section{d. Biaya Penyimpanan (CC)}

Besarnya biaya penyimpanan yang terjadi pada CV. Biji Kopi Makmur
Indralaya dinyatakan dengan persentase dari nilai persediaan rata-rata. Adanya peningkatan maupun penurunan jumlah persediaan kopi seruit dan kopi binder yang disimpan. Berikut ini penulis sajikan komponen biaya penyimpanan dan persentasinya.

Tabel 7

Biaya Penyimpanan Tahun 2016 dan 2017

\begin{tabular}{|c|c|c|c|}
\hline \multirow{2}{*}{ No } & Biaya & \multicolumn{2}{|c|}{ \%Biaya/ Tahun } \\
\cline { 3 - 4 } & Biaya Bunga & $\mathbf{2 0 1 6}$ & $\mathbf{2 0 1 7}$ \\
\hline 1 & Biaya Asuransi & 5,0 & 4,0 \\
\hline 2 & Biaya Pemeliharaan & 3,0 & 3,0 \\
\hline 3 & Biaya Sewa Gedung & 1,0 & 1,0 \\
\hline 4 & Pajak & 8,0 & 12,0 \\
\hline & Persentase Biaya Penyimpanan & $\mathbf{2 3 , 0}$ & 9,0 \\
\hline & & $\mathbf{2 9 , 0}$ \\
\hline
\end{tabular}

Sumber : CV. Biji Kopi Makmur Indralaya 
e. Persediaan Pengaman atau Safety Stock (SS)

Persediaan pengaman pada CV.

Biji Kopi Makmur Indralaya yaitu tersaji dalam komponen dalam tabel dibawah ini:

Tabel 8

Perhitungan Persediaan Pengamanan Kopi Seruit dan Kopi Binder Tahun $2016-2017$

\begin{tabular}{|c|c|c|c|c|c|c|}
\hline $\begin{array}{c}\text { Persediaan } \\
\text { (dalam pack) }\end{array}$ & \multicolumn{2}{|c|}{$\begin{array}{c}\text { Kebutuhan } \\
\text { Maksimum } \\
\text { perhari }\end{array}$} & \multicolumn{2}{|c|}{$\begin{array}{c}\text { Kebutuhan } \\
\text { Rata - rata } \\
\text { perhari }\end{array}$} & \multicolumn{2}{|c|}{$\begin{array}{c}\text { Lead time } \\
\text { perhari }\end{array}$} \\
\cline { 2 - 7 } & $\mathbf{2 0 1 6}$ & $\mathbf{2 0 1 7}$ & $\mathbf{2 0 1 6}$ & $\mathbf{2 0 1 7}$ & $\mathbf{2 0 1 6}$ & $\mathbf{2 0 1 7}$ \\
\hline Kopi Seruit & 150 & 166 & 69 & 77 & 3 & 3 \\
\hline Kopi Binder & 99 & 50 & 44 & 47 & 3 & 3 \\
\hline
\end{tabular}

Sumber : CV. Biji Kopi Makmur Indralaya 2016 dan 2017

2. Menganalisis titik pesanan kembali Reorder Point

RoP $=(L T \times A U)$

Keteranagan :

ROP : Reorder Point, Menentukan titik kembali sehingga perusahaan harus memesan kembali.

LT : Lead Time, Tenggang waktu antara pesanan kembali sampai dengan pesanan datang.

AU : Averrage, Usage, Pemakaian (penjualan rata-rata)

SS : Safety stock, besarnya persediaan pengaman.

\section{Tahun 2016}

a. Kopi Seruit

$$
\begin{aligned}
\mathrm{LT} & =3 \text { Hari } \\
\mathrm{AU} & =69 \text { pack } \\
\mathrm{SS} & =10 \% \\
\mathrm{ROP} & =(3 \times 69)+10 \% \\
& =207 \text { pack }+10 \% \\
& =277 \text { pack }
\end{aligned}
$$

\section{b. Kopi Binder}

$$
\begin{aligned}
\mathrm{LT} & =3 \text { Hari } \\
\mathrm{AU} & =44 \text { pack } \\
\mathrm{SS} & =10 \% \\
\mathrm{ROP} & =(3 \times 44)+10 \% \\
& =132 \text { pack }+10 \% \\
& =154 \text { pack }
\end{aligned}
$$

Dari perhitungan yang dilihat bahwa titik pesanan kembali tahun 2016 adalah kopi seruit sabanyak 277 pack dan kopi binder sebanyak 154 bungkus.

\section{Tahun 2017}

a. Kopi Seruit

$$
\begin{aligned}
\text { LT } & =3 \text { Hari } \\
\text { AU } & =77 \text { pack } \\
\text { SS } & =10 \% \\
\text { ROP } & =(3 \times 77)+10 \% \\
& =231 \text { pack }+10 \% \\
& =254 \text { pack }
\end{aligned}
$$

b. Kopi Binder

$$
\begin{aligned}
\text { LT } & =3 \text { Hari } \\
\text { AU } & =47 \text { pack } \\
\text { SS } & =10 \% \\
\text { ROP } & =(3 \times 47)+10 \% \\
& =141 \text { pack }+10 \% \\
& =155 \text { pack }
\end{aligned}
$$

Dari perhitungan yang dilihat bahwa titik pesanan kembali tahun 2017 adalah kopi seruit sabanyak 254 bungkus dan kopi binder sebanyak 155 bungkus.

\section{Menganalisis \\ Persediaan Pengamanan atau Safety Stock (SS)}


Safety stock $=($ Pemakaian Maksimum - Pemakaian Rata-rata) Lead Time

Keterangan :

$\mathrm{S}=$ Jumlah Persediaan Pengaman

$\% \mathrm{~S}=$ Persentase Persediaan Pengaman

$\mathrm{LT}=$ Waktu Tengang

$\mathrm{AU}=$ Pemakaian Rata- rata

\section{Tahun 2016}

\section{a. Kopi Seruit}

Safety Stock =

(Pemakaian Maksimum-Pemakaian

Rata-rata) Lead Time

$$
\begin{aligned}
& =(160-69) 3 \\
& =(91) 3=273 \text { pack }
\end{aligned}
$$

\section{b. Kopi Binder}

Safety Stock =

(Pemakaian Maksimum-Pemakaian

Rata-rata) Lead Time

$$
\begin{aligned}
& =(99-44) 3 \\
& =(55) 3=165 \text { pack }
\end{aligned}
$$

Dari perhitungan diatas dapt diketahui bahwa persediaan pengamanan untuk persediaan kopi seruit pada tahun 2016 adalah 273 pack dan persediaan pengaman untuk kopi binder sebanyak 165 pack.

\section{Tahun 2017}

\section{c. Kopi Seruit}

Safety Stock =

(Pemakaian Maksimum-Pemakaian

Rata-rata) Lead Time

$$
\begin{aligned}
& =(166-77) 3 \\
& =(91) 3=267 \text { pack }
\end{aligned}
$$

\section{d. Kopi Binder}

Safety Stock = (Pemakaian Maksimum-Pemakaian Rata-rata ) Lead Time

$$
\begin{aligned}
& =(88-47) 3 \\
& =(41) 3=123 \text { pack }
\end{aligned}
$$

Dari perhitungan diatas dapt diketahui bahwa persediaan pengamanan untuk persediaa kopi seruit pada tahun 2017 adalah 267 pack dan persediaan pengaman untuk kopi binder sebanyak 123 pack.

\section{Analisis Kuantitas Pemesanan Barang Dagang Yang Ekonomis \\ CV. Biji Kopi Makmur Indralaya} dalam melakukan pengelolahan persediaan barang dagangan, pemesanan barang dagangan hanya berdasarkan perkiraan saja tidak dianalisis dulu berapa jumlah seharusnya dibeli, sehingga CV. Biji Kopi Makmur Indralaya tidak dapat mengetahui berapa kali memesan barang dagangan dan banyak dagangan yang dipesan tidak sesuai dengan kebutuhan perusahaan. Apabila terjadi kelebihan barang dagangan maka CV. Biji Kopi Makmur Indralaya akan mengalami peningkatan biaya penyimpanan dan juga dapat mengakibatkan penurunan pendapatan dan juga akan dapat merugikan perusahaan.

Peneliti telah menunjukan hasil dari penggunaan metode EOQ, ROP, SS. Diatas maka peneliti menyajikan perbandingan antara peneliti dan CV. Biji Kopi Makmur Indralaya menggunakan metode EOQ, ROP, SS. Pada tabel dibawah ini. Agar menjadi acuan perusahaan dalam menetapkan persediaan barang dagangan pada CV. Biji Kopi Makmur Indralaya.

Dari perhitungan diatas menunjukan bahwa yang terjadi pada CV. Biji Kopi Makmur Indralaya sebelum dilakukan penelitiandengan menggunakan metode manual perusahaan didapat hasil yaitu total pemesanan untuk kopi seruit tahun 2016 dan 2017 sebanyak 36 kali hasil didapat dari keterangan CV. Biji Kopi Makmur Indralaya dengan melakukan pemesanan kopi seruit sebanyak 3 kali dalam 1 bulan maka pemesanan dalam 1 tahun yaitu $(3 \times 12$ bulan $=36$ kali) pemesanan dalam satu tahun. 
Untuk kopi binder melakukan pemesanan 4 kali dalam 1 bulan maka dapat dipastikan total pemesan kopi binder tahun 2016 dan 2017 yaitu (4 x 12 bulan $=48$ Kali) pemesanan dalam 1 tahun.

Adapun CV. Biji Kopi Makmur Indralaya dengan menggunakan metode EOQ, Rop dan SS yaitu dengan hasil EOQ dalam rupiah untuk kopi seruit pada tahun 2016 sebesar Rp. 79.125.657 dan pada tahun 2017 sebesar Rp. 83.871.823,. Untuk perhitungan persediaan EOQ dalam rupiah pada tahun 2016 untuk kopi binder sebesar Rp. 91.366.438,.dan pada tahun 2017 sebesar Rp. 83.871.823,.

Metode EOQ dalam unit untuk kopi seruit tahun 2016 sebanyak 197 pack dengan 23 kali pesanan dan tahun 2017 sebanyak 203 pack dengan 30 kali pesanan. Untuk kopi binder pada tahun 2016 sebanyak 209 pack dengan 24 kali pemesanan, lalu pada tahun 2017 sebanyak 186 pack dengan 27 kali pesanan.

Penetuan Reorderpoint (Rop) pada tahun 2016 untuk kopi binder sebanyak 277 per 18 kali pemesanan dan tahun 2017 sebanyak 266 pack dengan jumlah pemesanan sebanyak 23 kali. Lalu untuk kopi binder pada tahun 2016 sebanyak 258 pack dengan jumlah pemesanan sebanyak 19 kali, dan pada tahun 2017 untuk kopi binder sebanyak 243 pack dengan jumlah pemesanan 21 kali.

Penentuan persediaan pengamanan (safety stock) yaitu untuk kopi seruit tahun 2016 sebanyak 273 pack dan pada tahun 2017 sebanyak 267 pack, lalu untuk kopi binder pada tahun 2016 sebanyak 165 pack dan tahun 2017 sebanyak 123 pack persediaan pengaman.

\section{J. KESIMPULAN DAN SARAN \\ 1) Kesimpulan}

Dari hasil penelitian dan pembahasan mengenai perencanaan dan pengendalian persediaan barang dagang pada CV. Biji Kopi Makmur Indralaya, maka penulis mengambil kesimpulan yaitu :

a) Perencanaan dalam penyediaan atau anggaran hanya dilakukan dengan melakukan perkiraan saja. Tanpa melihat keaadaan, kapan harus barang dagangan harus dibeli dan sesuai dengan tingkat kebutuhan konsumen. Jadi persediaan barang dagang tidak efektif dan efisien, Sehingga terjadi kelebihan ataupun kekurangan persediaan. Hal ini terjadi karena hanya melihat karena hanya melihat realisasi tahun lalu tanpa menggunakan teori tertentu. Apabila persediaan barang dagang kurang maka akan menyebabkan waktu penjualan barang kepada konsumen menjadi terlambat dan dapat membuat perusahaan mengalamai kerugian sedangkan apabila terjadi kelebihan persediaan maka akan menambah biaya - biaya yaitu biaya penyimpanan dan biaya lain- lain.

b) Bahwa perencanaan persediaaan barang dagang pada CV. Biji Kopi Makmur Indralaya tidak efektif dan effisisen terlihat dari target dan realisasi persediaan barang dagang dari data yang diperoleh. Bahwa tidak tercapai beberapa jumlah yang ditargetkan maka inputnya tidak sesuai dengan outputnya.

\section{2) Saran}

a) Sebaiknya CV. Biji Kopi Makmur Indralaya dalam melakukan pemesanan barang dagang menggunakan metode EOQ agar 
dalam pemesanan dapat mengetahui jumlah pemesanan yang ekonomis untuk mengetahui berapa banyak jumlah yang harus dipesan tiap kali dilakukanya pemesanan itu sendiri.

b) Adapun pengendalian persediaan yang baik dalam pemesanan kembali yaitu dengan menggunakan titik pesanan kembali ROP (Reorder Point) sehingga CV. Biji Kopi Makmur Indralaya dapat mengetahui berapa banyak untuk melakukan titikpesanan kembali.

c) Diharapkan perusahaan menggunakan juga metode Safety Stock (Penetuan Persediaan Pengaman) agar tidak terjadi kekurangan dan kelebihan persediaan barang dagangan (kopi seruit dan kopi binder) pada CV. Biji Kopi Makmur Indralaya sehingga persediaan barang dagang lebih efektif dan efisien anggaran perusahaan sesuai dengan realisasi perusahaan.

\section{DAFTAR PUSTAKA}

Bayangkara, IBK. 2012. Audit Manajemen. Salembah Empat : Jakarta.

Dunia, Ahmad Firdaus, 2012, Akuntansi Biaya. Jakarta : Salemba Empat

Handoko .T. Hani, 2010, Manajemen. Edisi kedua. BPFE Yogyakarta : Yogyakarta

Jey Heyzer dan Barry Render.2010, Manajemen Operasi, Buku 1 edisi ke 9 Yogyakarta : UPP STIM YPKN

Mulyadi, 2012, Sistem Perencanaan dan Pengendalian Manajemen, Edisi Ketiga, Penerbit UPP STIM YKPN Yogyakarta.

Sugiyono, 2013, Metode Penelitian Bisnis. Bandung : Alpabeta

Sunyoto Danang, 2013, Dasar-dasar Manajemen Perusahaan, Penerbit PT. Buku Seru, Jakarta. 